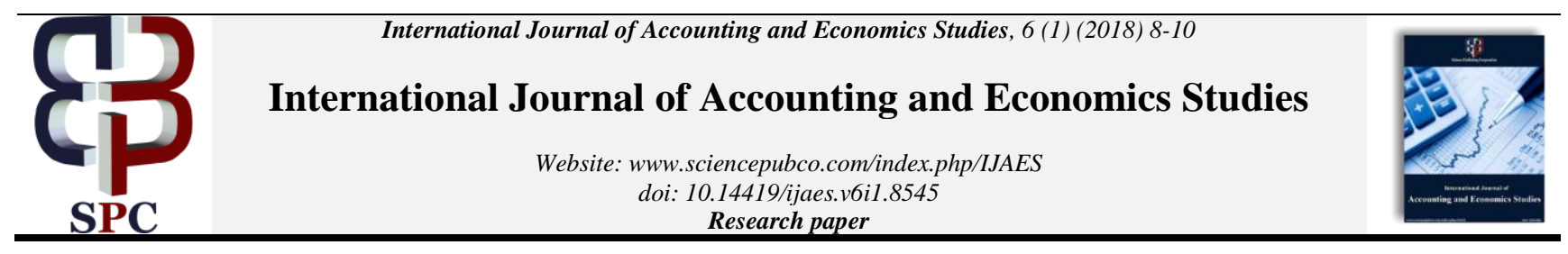

\title{
The impact of the quality of audit firms peer-review on tax evasion
}

\author{
Hazem M. Taha * \\ Krakow University of Economics \\ *Corresponding author E-mail: tahahazim@ hotmail.com
}

\begin{abstract}
This study examines the quality of audit firms peer-review impact on the audit activity on firms to disclose fair financial reports which will influences tax revenue of the countries and to reduce the Tax evasion. Audit Firms peer-review play a significant role in the countries tax evasion. The Audit Firms peer-review ensure that different investors and business in nations are confident and knowledgeable when making business decisions. The AICPA Peer Review is committed to improving the quality of auditing and accounting services. The program is a universal assessment whose value in serving the interest public and companies lies in its remedial and educational nature. Audit Firms peer-review has an impact on the collection of revenue considering the tests, there is an importance in the association between tax collected after auditing and before auditing. This demonstrates that there is increase in revenue collection after quality audit.
\end{abstract}

Keywords: Audit Environment; Corporate Tax Aggressiveness; Financial statement; Investor Protection; Litigation Risk; Quality audits.

\section{Introduction}

This study examines the quality of Audit Firms peer-review impact on the audit activity on firms to disclose fair financial reports which will influences tax revenue of the countries and to reduce the Tax evasion. Some of the previous studies carried out by different authors present 2 ways in which Audit Firms peer-review expertise and knowledge can help the public companies to evade income taxes and contribute to the nation's revenue. The AICPA Peer Review is committed to improving the quality of auditing and accounting services. The program is a universal assessment whose value in serving the interest public and companies lies in its remedial and educational nature. Audit Firms peer-review activity and expertise are related to the great level of client tax evasion amongst client companies that buy tax services from the audit company. In this case, sharing common Audit Firms peer-review helps to facilitate the septicity of tax evasion plans amongst clientele companies through different auditing networks. As far as numerous research works inspire the assessment of the connection between client tax evasion and auditor expertise, a lot of queries remain un responded to regarding the role of Audit Firms peerreview in the client tax evasion conduct.

\section{Discussion}

\subsection{Significance of peer-review quality audit}

Audit Firms peer-review play a significant role in the countries tax evasion. Audit Firms peer-review ensures that different investors and business in nations are confident and knowledgeable when making business decisions. Secondly it helps to support the quality of monetary statements and allow the investors to depend on the auditing independent evaluation of monetary reports in order to disclose and pay exact taxes. Moreover, quality of Audit Firms peer-review is related to issues that influence the ability of auditing companies to attain an audits significant aim- to attain reasonable guarantee that the money is totally free from material errors or misstatement. Lastly, quality of Audit Firms peer-review help to ensure any errors identified are communicated and addressed through audit report.

\subsection{Peer-review and quality audit control}

The AICPA Peer Review is committed to improving the quality of auditing and accounting services. The program is a universal assessment whose value in serving the interest public and companies lies in its remedial and educational nature. The peer-review reviews many engagements completed by companies in order to assure that companies will perform all engagements, in all companies according to professional standards. For example, Michas (2011) discovered that quality earnings are high in nations with superior professional development for quality audits and only for bigger clients.

The AICPA Peer Review helps the companies with suitable management to hire skilled and quality auditors and in this connection they are more dominant when the lawful enforcement is strong. Michas proposes that there are many benefits accrued from employing quality Audit Firms peer-review. For instance, when protection of investor is stronger in some companies, Audit Firms peer-review may be subjected to severe legal punishments for opportunistic conduct. The conflicting opinion is that companies in weak investment protection government might demand Audit Firms peer-review to replace the weak management. In agreement to this opinion Casanegra \& Bird (2012) discover that companies with equity issuances or debt are likely to recruit Audit Firms peer-review if protection of investor is weak, proposing that peer 
review audit firms play a significant governance function in weaker protection of investor nations. Moreover, Casanegra \& Bird (2012) discover that East-Asian firms with agency auditing recruit Audit Firms peer-review. In that sense Audit Firms peer-review are positively linked with transparency disclosure and this relationship is stronger in the court of law and very common in law nations.

Peer reviews at some point result in execution plans as well as corrective actions. Therefore, peer review helps the government to government to ensure all firms comply with the rules and regulation in disclosing taxes. Most of the companies enrolled in AICPA program are necessitated to have peer review after every 3 years.

\subsubsection{There are two types of peer-review}

1. System review helps in determining if the company's quality system control for accounting and auditing practice is compiled and designed to give the company reasonable assurance of performing and broadcasting in conformity with applicable professional standards in all information needed. This kind of review is for the companies that carry out engagements under the auditing standards statement and the government auditing standards. The reviewer which is known as Team Captain amongst other things tests, firm's engagement and reasonable high risk engagements in risk areas.

Becker, DeFond, Jiambalvo \& Subramanyam (1998) explain that system review connects similar audit tasks and the quality audit incorporates into expertise networks. Such networks or systems stand for channels of audit tasks. Audit Firms peer-review incorporate into the expert networks. Some of these networks stand for channels of expertise as well as knowledge spillover that offer superior-linked Audit Firms peer-review on info advantage. The findings indicate that companies with many connections to low tax companies through shared Audit Firms peer-review have high levels of tax evasion, hence proposing septicity effect. Most of the successful companies obey the rules of the tax system and no time they evade taxes. On the same note, Audit Firms peerreview works in favor government meaning they increase revenue.

2. Engagement review is for the registered companies that carry out services under SSAEs or services under SSARS that don't need system review. Engagement review are planned to determine if the engagements submitted for review and reported are in conformity with applicable expertise standards in all information. The aim of this review is to assess whether engagements submitted for evaluation conform with applicable accounting and auditing standards. All reviews conclude in a report. For system reviews, the report explains that whether the company's quality control structure offers reasonable assurance of conforming to professional standards in all financial statements.

McGuire et al., (2012) explain that that within public accounting companies' role as the external auditor in engagement review, there exist possibilities for bigger tax evasion and that general specialists are capable of combining their tax and audit specialists to create effective strategies that are advantageous to the clients from both a perspective of financial and tax report.

Alternative Substitutions for Quality Auditing -To assert that high-quality peer review auditing play as significant role in influencing company tax aggressiveness, previous researches indicate that auditing offered by business experts have the highest quality. Based on this, highquality auditing is negatively related to company tax aggressiveness, hence it must be assumed that auditing firms that offer high-quality audits have prominent impact.
Furthermore, for the engagement review, the report explains that the company's engagement tested by the reviewer must conform in all financial statements in respect to the professional standards. This review also comprises monetary statements as well as other relevant information submitted by the audited company and the accounting report together with applicable documentation, background information as well as required professional standards. The NYSSCPA manages peer reviews for the AICPA and manages peer reviews for nonAICPA member companies that are (1) needed to have a quality evaluation for NYS purposes of licensing or (2) who volunteer to have a quality review. Most of the companies that are registered in an AICPA program are needed to comply with standards of quality control. As the protection of investors become stronger, the possibility of identifying customer misreporting upsurges losses of legal action become bigger and the quality auditors have more reputational capital at risk.

\subsection{Impact of quality of audit firms peer-review on tax revenue}

Quality of audit peer review companies influences collection of revenue because it helps to promote compliance of the tax payers which upsurges revenue. It similarly helps to determine the accurateness of returns in order to make sure the correct taxes are delivered. With quality, audit liabilities are likely to be professed and issues that require adjustments are detected (MIRERA, 2014). Furthermore, it assists in collecting tax penalties and interests which therefor upsurges collection of revenue. Audit Firms peerreview likewise executes some changes to remove such tax avoidance. In this case, quality audit is absolutely related to collection (MIRERA, 2014).

Audit Firms peer-review has an impact on the collection of revenue considering the tests, the auditing is important in the association between tax collected after auditing and before auditing. This demonstrates that there is an increase in revenue collection after the quality audit. That in principle signifies that the more quality auditing is carried out the more a lot of revenue is collected. Hence it is appropriate to say that quality audit is directly linked to collection of revenue (MIRERA, 2014). All Audit Firms peerreview are significant in that they increase the collected revenue and in that case ought to be inspired as it helps the administration in collecting correct tax income essential for maintaining monetary and economic order, budget as well as stability to make sure that sufficient revenues are filed by the business people and companies (MIRERA, 2014). This helps to organize the extent of tax evasion and tax avoidance, to make sure strict complying with laws of tax by the tax payers, to enhance the extent of complying voluntary by the business as well as to make sure that remaining debt is collected and submitted to the tax authority or management Wandugo (2013) carried out a study on tax compliance in Kenya. The research indicated that since the introduction of I-Tax after auditing recommendation, there has been a decrease in fines and penalties. Compliance with I-Tax has caused a decrease in tax refunds. This means that through Audit Firms peer-review there has been an upsurge in tax collection. This is because I-Tax has exposed all company records online making auditing efficient. The study also disclosed that taxpayer accounts records are accurate, reliable and up to date. On the same note, due to Audit Firms peer-review and I-Tax, there has been a decrease in fraud cases as well as tax evasion because there has been the timely filing of the returns. Also, the research discovered that there has been a decrease in audit period, since the work of Audit Firms peer-review has been simplified making it easy access to the financial statements ( ESBON, 2014). 


\subsection{Role of quality of audit firms peer-review in tax aggressiveness}

The key role of the audit companies peer review is to reveal the information regarding whether monetary statements, as well as associated disclosures, present just facts in relation to the client company's monetary condition in conformism with Generally Accepted Accounting Principles (GAAP). Due to the fact that income tax can amount to about $50 \%$ of a public company's net revenue, Audit Firms peer-review must frequently consider to total amount sensible to monetary statements (Kanagaretnam, Jimmy, Yeow, \& Lobo, 2017). Therefore, quality of Audit Firms peer-review assess the legitimacy of accumulated taxes payable as well as tax conditional liabilities on the balance sheet, revenue tax expenditure on the income report, as well as the related report disclosures to offer sufficient guarantee to the investing public regarding the suitability of these disclosures and items. Since any significant info regarding uncertain tax transactions is always concealed in these disclosures and accounts, the experienced auditors similarly have to evaluate whether the clienteles take part in possible tax abusive transactions that can be confronted in case detected by the tax agency.

Quality of Audit Firms peer-review, if essential, could need clienteles to view properly the tax related items on the monetary reports, for instance by recording unacknowledged or reserve tax benefit adjustment, thus up surging recounted tax expenditures and decreasing the monetary statement benefits of taking part in tax evasion. By making sure that taxable income and book are properly reported in the monetary reports, Audit Firms peerreview circuitously decrease company's capabilities as well as incentives to evade tax since large book tax difference can be a possible alarm, that up surges the possibility of detection by the tax consultants (Kanagaretnam, Jimmy, Yeow, \& Lobo, 2017). The Audit Firms peer-review have inducements to influence the clienteles aggressive tax activities for many reasons. First, companies that take part in aggressive tax behavior have greater chances of restatements and errors since managers can use several accounts like approximated of accumulated taxes, tax contingency reserves and valuation allowances to manage earnings. Due to the fact that customers aggressive monetary statement is definitely linked to Audit Firms peer-review risk of legal action, tax aggressiveness has higher chances of increasing legal action risk of the auditing expert when restatements and errors happen.

(Kanagaretnam, Jimmy, Yeow, \& Lobo, 2017) indicate that news regarding company's involvement in aggressive tax planning decrease the prices of stock and upsurges the risk of stock price crush. The possible loss of the wealth of shareholders can as well precipitate legal action against the company as well as its Audit Firms peer-review. Thus, the Audit Firms peer-review that audit clienteles that are tax aggressive face high-risk engagement. In addition, the behavior of tax aggressiveness calls into the question the risk profile as well as the integrity of the management and aggravates the agency challenges between the company as well as its stakeholders. Research works have indicated that tax aggressive behavior driven by top tone, and tax assertiveness might show attitude management towards compliance with rules and regulations. A feebler tone at the top, as well as its effect on the environment control, can upsurge the possibility that the stakeholders may not be capable of uncovering possible monetary misconduct in the company. Self-serving bosses similarly have enticements to use tax evasion practices to cover rent-seeking behavior which again surges the danger faced by auditors (Desai and Dharmapala 2006).

\section{Conclusion}

Quality audit actually has a tremendous impact on revenue collection, from the above research works there is a substantial relationship between collected tax after auditing has been carried out and before the auditing. This plainly shows that quality audit upsurges collection and revenue and reduces tax evasion. This demon- strates that in every company where the quality audit is carried out, more revenue is collected. Therefore, it is correct to say that quality audit is directly linked to the collected revenue. That is to mean quality audit are vital in that they have additional value to revenue and hence must be inspired as it helps the government to collect the right amount of revenue. The research discovered that monetary performance can be accounted for by tax compliance changes, size of the company, tax refunds claims, and tax evasion. The research discovered that one upsurge in compliance of tax would upsurge monetary performance, while one surge in tax avoidance would reduce monetary performance, on the other hand, a unit upsurge in duty reimbursements claims cause reduction in monetary performance as well as more unit upsurge company size cause reduction in monetary performance.

\section{Acknowledgement}

I acknowledge my family for the motivation they gave me throughout the study. Similarly, for being kind, patient, understanding as well as giving moral support in my study.

I also acknowledge my professor for rudimentary knowledge in the guidance of the research support and patience throughout the research. Dr. Hab. Piotr Wojtowicz, Prof. UEK has been source of encouragement as struggled with the work. To me, this professor is incomparable.

\section{References}

[1] Becker, DeFond, Jiambalvo \& Subramanyam (1998), The Effects of Audit Quality on Earnings Manipulation. Contemporary Accounting Research 15 (1): 1-24.

[2] Casanegra, M.J. \& Bird, M.R. (2012). The reform of tax administration. improving tax administration in developing countries. IMF, Washington DC.

[3] Cobham, A. (2005). Tax evasion, tax avoidance and development finance. Queen Elisabeth House Working Paper No. 129. Oxford: Oxford University

[4] Desai, M., Dharmapala, D., (2006). Corporate tax avoidance and high-powered incentives. Journal of Financial Economics 79: 145179.

[5] ESBON, W. (2014). EFFECTS OF ELECTRONIC TAXATION ON FINANCIAL PERFORMANCE OF AUDIT FIRMS IN KENYA.

[6] Kanagaretnam, K., Jimmy, L., Yeow, C., \& Lobo, G. (2017, July). Relation between Auditor Quality and Corporate Tax Aggressiveness: Implications of Cross-Country Institutional Differences.

[7] McGuire, S. T., T.C. Omer, and D. Wang. (2012). Tax Avoidance: Does Tax-Specific Industry Expertise Make a Difference? The Accounting Review, 87(3): 975-1003

[8] Michas, P., (2011). The importance of audit profession development in emerging market countries. The Accounting Review 86(5): 1731-1764.

[9] MIRERA, D. (2014, November). THE EFFECTS OF TAX AUDIT ON REVENUE COLLECTION: CASE OF KENYA REVENUE AUTHORITY. 